\title{
Inclusive Human Resource Management Practice to Change the Organizational Climate
}

\author{
Ulfah Fatmala Rizky ${ }^{1^{*}}$ \\ ${ }^{1}$ Universitas 17 Agustus 1945 Jakarta
}

\begin{abstract}
Abstract This study aims to describe and analyze the organizational climate change process in Mandiri Contact Center (MCC) Yogyakarta which employs people with disabilities since the implementation of the Mandiri Kriya Difabel Program. A qualitative method with an instrumental case study approach is used in this study. To collect the data, the researcher uses interview, observation and documentation study technique. The results show that by implementing an inclusive human resource management, the Mandiri Kriya Difabel Program has succeeded to change an exclusive organizational climate into an inclusive disability organizational climate. This is the first study which combines Lewin's Three Step Change Model, Social Model of Disability, and Inclusive Dimensions on Organizational Climate as a framework to research a disability inclusive organizational climate change. This research provides an inclusive method to manage employees with disabilities and a new academic reference on organizational change study.
\end{abstract}

Keywords: inclusive organizational climate, organizational change, human resource management, people with disabilities

\section{Research Background}

Organizational climate in a workplace can eliminate discrimination, increase equality, and distribute social justice for workers with disabilities (Nishii \& Rich, 2014; Roberson, 2006; Shore et al., 2011) who have experienced dismissal or rejection in the workplaces as a result of exclusion and discriminative attitudes (Shier, Graham, \& Jones, 2009). For example, Nunik Wahyu Lestari's experience. Nunik is an one-handed woman who repeatedly being rejected when applying for jobs due to job recruiters' discriminative attitudes on Nunik's physical condition (Sorot Gunung Kidul, 2018) Another bad experience also happened to Sri Sukarni, Chair of the Indonesian Association of Women with Disabilities (HWDI), West Nusa Tenggara Province (NTB) (Suara NTB, 2017). These conditions arise from social structure which includes institutional discrimination, physical environment discrimination, behavioral discrimination, stigmatization, pessimistic attitudes, and high-cost consideration due to recruiting people with disabilities (Kulkarni \& Lengnick-Hall, 2014; Sellevoll, 2016; Yeo \& Moore, 2003). 
On the one hand, creating an inclusive climate organization for people with disabilities is a complicated process because it requires a combination of disability model and organizational change model (Ndzwayiba \& Ned, 2017). On the other hand, studies on people with disabilities inclusive organizational climate change are scarce. Previous studies on organizational climate change had more focus on gender, culture, and ethnic inclusion issues such as Andrews \& Ashworth (2015) found that gender and ethnic minority representation increased inclusive climate organization and decreased discrimination and bullying practice in workplace; Nishii (2013) found that inclusive climate organization could reduce gender bias and stigma against women; and Stevens, Plaut, \& Sanchez-Burks (2008) found that all-inclusive multiculturalism (AIM) method positively and effectively support the inclusive organizational change process by infusing all-inclusive language for communication among diverse group in organization. Meanwhile, the only one study which researched on people with disability inclusive organizational change was conducted by Ndzwayiba \& Ned (2017). The study found that transformative leadership culture, leadership accountability, and spreading disability mainstreaming affected an inclusive organizational change for people with disabilities.

In addition, Lengnick-Hall, Beck, \& Lengnick-Hall (2011) found that organizational change is inevitable. Therefore, every organization must prepare itself to change and maintain these changes. To sustain the changes that occur in organizations, it is necessary to pay attention to the implemented human resource management methods due to their significant effect on the behavior and attitudes change of organization members which will affect the organizational change process. Similar findings were also conveyed by Herzig \& Jimmieson (2006) which stated that human resource management has a vital role to play in managing organizational changes and the role of middle-level managers is significant in that uncertain times. Based on a number of previous studies, the role of inclusive human resource management practice in changing organizational climate to be inclusive for people with disabilities is still undiscovered (Ndzwayiba \& Ned, 2017; Nishii, 2013; Shore et al., 2011). Therefore, this study aims to fill that research gap.

Meanwhile, studies on inclusive human resource management and inclusive organizational changes for people with disabilities in Indonesia, especially in the workplace, are very scarce even though the inequality of the non-disabled workforce to the workforce with mild disabilities was $13.68 \%$, while the inequality of the non-disabled workforce to the workforce with severe disabilities was $50.13 \%$ (Halimatussadiah, Nuryakin, Muchtar, Bella, \& Rizal, 2017). This condition is similar to people with disabilities in Africa. On the one hand, employment for people with disabilities is quite inaccessible. On the other hand, research on inclusive human resource management practices is also scarce (Ndzwayiba \& Ned, 2017).

In 2015, Indonesian Minister of Manpower and Indonesian Minister of StateOwned Enterprises (SOEs) signed a Memorandum of Understanding (MoU) No: 13/NK 
/MEN/XII/2015 on the Placement and Training of Workers with Disabilities in SOEs offices. The MoU aims to fulfill the right to work for people with disabilities in Indonesia. Mandiri Contact Center (MCC) Yogyakarta is one of the PT Bank Mandiri (Persero) Tbk branch offices which is one of the major SEOs in Indonesia. In addition, MCC Yogyakarta was the only state-owned company which earnestly implemented the MoU by implementing the Mandiri Kriya Difabel Program during 2016 to 2018. This program encouraged the organizational change to be inclusive for people with disabilities through inclusive HRM practices. This condition is a background of the case study in this research.

In addition, a terminology also plays a significant role to eliminate discrimination towards people with disabilities. Therefore, the Government of Indonesia changed the 'handicapped (penyandang cacat)' term to 'people with disabilities (penyandang disabilitas)' term. Indonesian activists on disability issues also use another inclusive term for people with disabilities that is 'difabel'. 'Difabel' is an English acronym of differently-abled people (Purwanta, 2012). This term was first introduced in Indonesia by Fakih (1999) and it aimed to resist the hegemony of normalization and ableism in society (Suharto, Kuipers, \& Dorsett, 2016) which excludes people with disabilities to actively contribute and participate in social life. Due to this reason, PT. Bank Mandiri (Persero), Tbk. used the 'difabel' term for The Mandiri Kriya Difabel Program. In addition, this term was used in many previous scientific literatures (Carrico, 2014; Latifah \& Himawanto, 2017; Maftuhin, 2014, 2016; Ningsih, 2014; Rahayu, Dewi, \& Ahdiyana, 2013; Rahmatin, 2013; Shojaei \& Shahabi, 2018).

\section{Literature Review}

\subsection{Inclusive Human Resource Management Process}

In this study, the author adapted the human resource management practices introduced by Melo Oliveira, Dias, and Barbosa (2017: 13-23). There are five components presented by de Sá et.al. (2017: 13-23), namely: first, the recruitment process which aims to integrate human resources. Second, the selection process which aims to select individuals to join an organization. The selection process must be fair and equal to all candidates, including people with disabilities. It means that the recruitment and selection process for candidates with disabilities must be in accordance with the merit system. Third, the socialization process which aims to integrate new members with previous members and provide an orientation about the organization, this process is more than just an introduction. The fourth and fifth processes are training and development. These two stages aim to improve and develop organizational performance by building organizational human resource capacity.

\subsection{Changing As Three Steps Model}

The organizational change explains the organizations movement from the current conditions to the desired conditions. An organizational change can be both a threat and an opportunity for an organization development (Mills, Dye, \& Mills, 2008). It 
is an inevitable cyclical process in organization (Salaman \& Asch, 2003) which caused by using new technology (de Andrade, Albuquerque, Teófilo, \& da Silva, 2016), implementing new government regulations (Yonnedi, 2010), competition (Hossan, 2015; Otchere-Ankrah, 2015), cash flow problems (Fitzgerald \& Stirling, 1999), data security (Cline, Guynes, \& Nyaboga, 2010) and leadership changes (Agbim, 2013; Belias \& Koustelios, 2014).

Hossan (2015: 54) classifies organizational change management theory into three categories, namely: the first category is management theories that focus on change content issues, such as the Burke-Litwin theory which examines individual and organizational performance, and Vollman's imperative transformation model which discusses the level of the change process. The second category is theories that focus on contextual issues including internal conditions such as organizational structure, new specialists to operate new technology, and previous change experiences, and external conditions such as changes in government regulations and technological advances. The third category is theories that focus on the organizational change process. This category was initiated by Lewin (1947: 35) who introduced the Changing as a Three Steps Model. Then, this model was continued by a number of academics until other organizational change process models emerged. In the study of organizational change, Kurt Lewin is the most frequently mentioned scientist. His contributions to organizational studies laid the foundation for other organizational change theories. This is what underlies the author to use Lewin's theory of organizational change in this study.

According to Lewin's change model, a successful change depends on social groups' willingness to leave their old pattern of thinking and behavior (Collins, 1998). Therefore, a change agent must convince organization members to leave the current status quo conditions. Changing as Three Steps Model is a part of Kurt Lewin's planned change theory which includes three aspects: unfreezing the present level, moving to the new level, and refreezing the group's life of the new level (Burnes, 2004a, 2004b; Lewin, 1974; Mills et al., 2008). The groups are an important level in understanding change and always in a quasi-stationary equilibrium which is analogous to a flowing river. The river flow is influenced by internal and external forces that can change the direction of the river flow or hold it. This condition is called as a continuous state of adaptation (Mcaleese, Creed, \& Zutshi, 2013). Therefore, an organization should develop a specific method to preserve the required behavioral change and to resist the return of old organization behavior.

As organizational studies develop, the Model of Changing as Three Steps also develop as a process-based theory of change (Hossan, 2015). This change model consists of three stages. The first stage is the unfreezing stage. At this stage, the organization should brainstorm its members to understand and believe about the background and expected goals of organizational change. The second stage is the moving stage where changes actually occur and the organization moves to the desired conditions. The 
organizational change includes several forms as the existence of new policies, new procedures, new structures, new values, and new behaviors that develop in organization. The third stage is refreezing. At this stage, the organization provides support for ongoing changes to maintain the existing changes and the new organizational behavior. Implementing a reward system is a common method applied in this stage (Burnes, 2004a, 2004b; Coghlan \& Rashford, 2015; Collins, 1998; Mills et al., 2008)

\subsection{Social Model of Disability}

Before the 1990s, most of the academic literature on disability issues centered on medical discourse or medical models of disability such as Berkowitz \& Johnson (1970) who argued that disability is an individual problem. The medical model of disability defined disability or impairment as damage to motor, sensory, mental, and intellectual function. Michael Oliver referred to this perspective as a personal tragedy theory (Barnes, 2012; Oliver, 1983, 2019). Personal tragedy theory shows the limitations experienced by people with disabilities solely due to their physiological and/or psychological conditions that differ from the so-called a 'normal' society, these conditions are considered as deviations. Consequently, people with disabilities are excluded from participating in social life and labeled as 'sick people'. This medical model of disability has surfaced the stigma on people with disabilities.

As time goes by, disability studies show a progressive development. Social, economic, and political dysfunction on people with disabilities turned from personal tragedy into social oppression. This change is called the social model of disability. This model define disability as a loss or limitation of the activity of someone who is impaired caused by the relationship between an impaired individual and any form of ableism in the environment and social structure (Oliver, 1983). In addition, ableism defined as the devaluation of disability (Hehir, 2002) and preference or favoritism to the non-disabled people (Wolbring, 2008)

\subsection{Dimensions of Inclusive Organizational Climate}

Inclusion and diversity are like two inseparable currencies. Therefore, the understanding of the relationship between inclusion and diversity is important in inclusion issues. Diversity is defined as an organizational reality (Ferdman, 2014) and focuses on organizational demographic conditions (Roberson, 2006; Shore, Cleveland, \& Sanchez, 2018) while inclusion focuses on eliminating marginalization, exclusion (Nishii \& Rich, 2014) and obstacles thus the group can fully participate and contribute in the workplace (Roberson, 2006). The inclusion process starts from providing equal access to resources, participating in making decisions, and promoting positions which encourages the dominant and Non-dominant group accept and respect each other (Shore et al., 2018,2011 ). However, this process must not eliminate the different identities of each group. In the concept of inclusion, these differences are recognized as uniqueness and diversity of identities that must be appreciated. Hence, two components of inclusion are 
ownership (belongingness) and uniqueness. These components underlie current inclusion literatures (Ferdman, 2014; Jansen, Otten, van der Zee, \& Jans, 2014; Nishii \& Rich, 2014; Sabharwal, 2014; Shore et al., 2018, 2011).

The inclusion concept in this study was developed by Shore et al. (2011) from Optimal Distinctiveness Theory (ODT) submitted by Brewer (1991). An inclusive workplace is built on the basis of pluralistic values that respect the entire cultural perspective of its employees (Mor Barak \& Daya, 2014). Inclusion involves recognizing, rewarding, and utilizing diversity between groups to work together productively without categorizing differences between them, and using these differences for positive things (Ferdman, 2014; Nishii \& Rich, 2014; Sabharwal, 2014). The practice of inclusion is a cyclical and dynamic process because inclusion is formed continuously (Ferdman, 2014). The culture of inclusion requires a radical change including policy changes, behavioral changes, and changes in organizational practices that are designed for organization members to contribute their abilities in achieving organizational goals (Miller \& Katz, 2002).

Organizational culture and organizational climate explain about how organization members observing, feeling, and understanding their work environment. Therefore, the concepts of organizational culture and climate are the basic foundation to understand and analyze organizational phenomena (Ostroff, Kinicki, \& Muhammad, 2013). Organizational culture differs from the organizational climate due to the distinguished definition. Organizational climate is defined as a reflection of the internal environment characteristics of organizations while organizational culture is all belief, expectations, values, behaviors, and norms that contribute to achieve organizational goals (El-Majali, 2016). In addition, the organizational climate focuses on the situation and its relationship with employees' perceptions, feelings, and behaviors. Therefore, the organizational climate is easily recognized by individuals through the physical appearance of the organization, the attitude of employees, and the treatment of visitors and new employees. The organizational climate is also temporal, subjective, and easily manipulated by authority figures while organizational culture is the opposite. Organizational culture has a strong root in history and forms more stable values. It is resistant to manipulation because it deals with ideologies and fundamental assumptions (Ostroff et al., 2013). Nishii \& Rich (2013) define organizational climate as a shared perception of employees about organizational policies, practices and procedures, both formal and informal. Their three dimensions of inclusive organization concept are: first, the organization is required to implement fair work practices between marginalized groups and their counterparts. The second dimension is the organization is required to focus on adapting integration strategies that drive the adaptation process of both parties. The third dimension is implementing inclusive decision making by providing several channels of bottom-up communication, seeking feedback from organization members, being open to alternative ideas, and considering all information received from members of the organization. 


\section{Research Methodology}

This study used a qualitative research method with an incremental case study approach (Creswell, 2007; Hartley, 2004; Saldana, 2011; Simons, 2014; Yin, 2003). Data collection was carried out using unstructured interview technique (Saldana, 2011), direct observation (Walshe, Ewing, \& Griffiths, 2011), documentation study (Yin, 2003) and the use of video recordings (Adami, 2009; Heath, Hindmarsh, \& Luff, 2010; Jewitt, 2012; Patterson, 2018). This study used the Interactive Model Data Analysis and triangulation of data sources, methods, and data types for validating the data (Miles, Huberman, \& Saldana, 2014). This study used an implied consent and written approval from Mandiri University, PT. Bank Mandiri (Persero), Tbk. Therefore, this study met the research code of ethics (Berg \& Lune, 2017; Saldana, 2011). Overall, this research was conducted from March to November 2018.

Table 1. Informant Characteristics

\begin{tabular}{|c|c|c|}
\hline Position & Disabilities & Qty \\
\hline \multicolumn{3}{|l|}{ A. Mandiri Contact Center (MCC) Yogyakarta } \\
\hline 1. Department Head (DH) & - & \\
\hline \multicolumn{3}{|l|}{ 2. Retail Banking Services (RBS) } \\
\hline a.Section Head (SH) & - & \\
\hline b. $\quad$ Team Leader $(\mathrm{TL})$ & - & \\
\hline c. $\quad$ Agent & Physical disabilities & \\
\hline \multicolumn{3}{|l|}{ 3. Credit Card Services (CCS) } \\
\hline a.Section Head (SH) & - & \\
\hline Team Leader (TL) & - & \\
\hline c.Agent & - & \\
\hline Agent & Physical disabilities & \\
\hline \multicolumn{3}{|l|}{ 4. $\quad$ Resources and Infrastructure Management (RIM) } \\
\hline a.Section Head (SH) & - & \\
\hline Staff & - & \\
\hline \multicolumn{3}{|l|}{ 5. Quality Control Monitoring (QCM) } \\
\hline a.Sign Officer (SO) & - & \\
\hline b. $\quad$ Staff & - & \\
\hline \multicolumn{3}{|c|}{$\begin{array}{l}\text { B. Ministry of Empowerment, Republic of Indonesia (Directorate General of Manpower } \\
\text { Development and Expansion of Employment Opportunities (Binapenta \& PKK)) }\end{array}$} \\
\hline \multicolumn{3}{|l|}{$\begin{array}{l}\text { Head of Sub-directorate for Special Workers } \\
\text { Placement (period of } 2014-2017 \text { ) }\end{array}$} \\
\hline \multicolumn{3}{|c|}{$\begin{array}{l}\text { C. Ministry of Social Affairs, Republic of Indonesia (Vocational Rehabilitation Center for } \\
\text { People with Physical Disabilities (BBRVBD)) }\end{array}$} \\
\hline $\begin{array}{l}\text { Head of BBRVBD at Cibinong Sub-district (period } \\
\text { of } 2016-2017 \text { ) }\end{array}$ & - & \\
\hline Total number of informants & & 3 \\
\hline
\end{tabular}

There are thirty-three informants who participated in this unstructured interview with details as in table 1 . Direct observations in this study included the activities of MCC 
Yogyakarta employees. Observation of the activities of MCC Yogyakarta employees was carried out to obtain data related to the interaction of disabled and non-disabled employees, the observation of these activities consisted of sports activities and lunch activities. This study also used documents published by online mass media, previous studies, written reports, and photos of the research location. In addition, this study used an existing video technique (Jewitt, 2012) to collect data from the Youtube video. This research used two existing videos published on YouTube entitled "Mandiri Sahabat Difabel" which published by Breidea Creative on January 26, 2017, and "Seri Video Perusahaan Inklusi: Mandiri Contact Center Yogyakarta" published by Kerjabilitas on October 1, 2017.

\section{Results}

\subsection{Unfreezing: "Spirit Memakmurkan Negeri"}

The unfreezing stage began with the Bank Mandiri inclusion program launching ceremony. The program named Mandiri Sahabat Difabel which includes The Mandiri Kriya Difabel Program as its subprogram. The program implementation is an embodiment of the Employment Value Proposition (EVP) of PT. Bank Mandiri (Persero), Tbk. and the accomplishment of the MoU No: 13/NK /MEN/XII/2015 on the Placement and Training of Workers with Disabilities in SOEs offices. In this stage, the author analyzed the supporting and inhibiting factors to change quasi-stationary equilibrium in MCC Yogyakarta. This study found that three factors has supported the organizational change climate in MCC Yogyakarta are first, actualizing the EVP of PT. Bank Mandiri (Persero), Tbk. that is "Spirit Memakmurkan Negeri". This EVP was based on the country prosperity-oriented business value. This value was manifested in the Mandiri Kriya Difabel Program implementation. The Department Head (DH) of MCC Yogyakarta stated:

"Whoever eats and drinks from Indonesian soil and water should return to society... we cannot prosper alone while our environment does not. It is impossible for us to be full but all around us are hungry. Yes maybe, the truth is we are both progressing, both successful" (interview on December 7, 2018).

Based on the author's analysis, the Mandiri Kriya Difabel Program implementation is indeed an appropriate manifestation of the EVP of Bank Mandiri. The inequality access and stigma experienced by the workforce with disabilities complicate their job competition against the nondisabled workforce. The second supporting factor for inclusive organizational climate change is the implementation of the MoU No: 13/NK /MEN/XII/2015 on the Placement and Training of Workers with Disabilities in SOEs offices. By signing the MoU on December 11, 2015, the Ministers aimed that SOEs could become examples for other job providers to recruit people with disabilities as stated by Head of Sub-directorate for Special Workers Placement (period of 2014 - 2017):

"The fundamental reason that we (the Indonesian Government) encourage private companies to accept disabilities, should have been started by the government, which has many state-owned companies (BUMN). So, before asking private 
companies to accept disabilities, the government should prioritize BUMN as an example" (interview on April 25, 2018).

SOEs also have three other tasks except placing and training disabled workers which are first, providing employment opportunities and equal treatment for people with disabilities. Second, protecting employees with disabilities based on the type and degree of their disabilities. Third, offering inclusive job training for people with disabilities. The third driving factor is also the implementation of the Law on Disabilities. The Indonesian government has implemented Law No: 8 of 2016 on People with Disabilities. This Law regulates an affirmative policy of 2 percent quotas that guarantee inclusive access for people with disabilities to work in the Central Government office, Regional Government office, Regional-Owned Enterprises (ROEs) companies, and SOEs companies.

The inhibiting factor for quasi-stationary equilibrium change is the information and practices limitation of inclusive human resource (HR) management. Fortunately, the DH of MCC Yogyakarta initiated to seek information from several people with disabilities organizations in Yogyakarta. The DH of MCC Yogyakarta said:

\begin{abstract}
"When we started, we didn't even know what to do. Then we took the initiative to contact friends who were involved with disabilities. At the time of recruiting disabled workers, we also discussed their needs when working here (MCC Yogyakarta)" (interview on December 7, 2018). Based on these data, the success of the quasi-stationary equilibrium change in MCC Yogyakarta is inseparable from the role of DH of MCC Yogyakarta who always motivated and inspired all staff at MCC Yogyakarta. The DH of MCC Yogyakarta frequently reminded the employees that:

"the organization cannot achieve extraordinary results if no changes are made. Like a person who is hoeing, if every day hoeing $50 \mathrm{~m} 2$ then do not ever expect to get $100 \mathrm{~m} 2$ of results every day" (interview on December 7, 2018).
\end{abstract}

In addition, the DH of MCC Yogyakarta also consistently socialized the Mandiri Kriya Difabel Program to all staff. These activities successfully created a sense of survival anxiety among the management and staff of MCC Yogyakarta. The changes are inevitable when survival anxiety has arisen because people will feel the fear of failure if they do not change (Schein, 1995). Based on this analysis, the author concluded that the driving factors for the change in quasi-stationary equilibrium were stronger than the inhibiting factors.

\title{
4.2 Moving: "Moving for Inclusion"
}

The second stage is the moving stage. This study focuses on the modification of the human resource management (HRM) method at MCC Yogyakarta. The changes in the HRM method including recruitment, selection, outreach, training, and employee capacity building (de Sá, de Melo Oliveira, Dias, \& Barbosa, 2017). The first HRM process is recruitment. Limited information about disabled workers has encouraged MCC Yogyakarta to cooperate with two public institutions. The first institution is the Bina 
Daksa Vocational Rehabilitation Center (Balai Besar Rehabilitasi Kejuruan Bina Daksa/BBRVBD) in Cibinong which is under the Ministry of Social Affairs of the Republic of Indonesia. Informant 18 stated "I continued my job training at BBRVBD in Cibinong...I passed the job test which was given by MCC Yogyakarta recruitment staff..." (interview on April 23, 2018). The second institution is Saujana which is a non-governmental organization (NGO) that provides an online job-seeking platform for people with disabilities namely Kerjabilitas.com. Informant 121 stated "I got the information from website. There is Kerjabilitas. I found a job vacation in Mandiri Yogya then I applied to work here" (interview on Mei 2, 2018). In addition, Informant I13 said:

"There was a job fair event at Gadjah Mada University in Yogyakarta, one of its booths is Kerjabilitas which promoted a job vacation at MCC Yogyakarta. Then, I applied" (interview on April 25, 2018).

The Head of BBRVBD at Cibinong Sub-district (period of 2016 - 2017) said "it (PT. Bank Mandiri (Persero)), Tbk was the first recruiter who came to (BBRVBD) to directly recruited 40 trainees here" (interview on April 27, 2018).

The second HRM process is a selection that includes administrative selection, psychological test, call center agent skill test, and interview test. Although there is a slight difference in the psychological test, the difficulty level of work skill and interview assessment is the same for both disabled workers and non-disabled workers. The SO of QCM said:

"Most of the selection process is equal for workers with disabilities and nondisabled workers except for the psychological test. Prospective employees with disabilities get a simpler psychological test than non-disabled employees" (interview on Mei 2, 2018)

The third HRM process is socialization. MCC Yogyakarta uses a lottery system to determine the working cubicle on every working day. This system aims to encourage active interaction between workers with disabilities and non-disabled workers. This simple change was able to remove barriers during the integration process. The fourth HRM process is on-the-job training (OJT) for all new employees that aims to improve the knowledge, skills, and personality of new employees before they actually carry out their duties as call center agents. MCC Yogyakarta provides intensive and extended training time for employees with disabilities due to the unequal capacity of employees with disabilities and non-disabled employees, as stated by informant 121:

“...the regular employees (non-disabled employees) were given three months (for OJT) while disabled employees were given six months (for OJT)..." (interview on Mei 2, 2018).

The unequal skill is a domino effect of discrimination that has been faced by people with disabilities (Sen, 2000; Yeo \& Moore, 2003). Therefore, the decision to provide extended time for employee with disabilities during OJT is a fair decision. The last HRM process is the employees' capacity development. MCC Yogyakarta develops disabled workers' capacity by providing opportunities for disabled workers to become 
mentors and take part in the Best Contact Center Indonesia competition. The competition was held by the Indonesia Contact Center Association (ICCA) from July 4 to August 2, 2018. This study found that these five changes on HRM process provide equal and fair access for disabled workers to develop their work skills.

\subsection{Refreezing: "Migunani Tumraping Liyan"}

The third phase of organizational change process is refreezing phase, this stage aims to preserve the changes or new values that have emerged in the organization (Lewin, 1974). MCC Yogyakarta has not formally written policy regarding disabled employees management and inclusive organizational climate change process. However, this study found that the working environment at MCC Yogyakarta was very supportive of accepting new values and behavior which restraint the new rounds of disconfirmation (Schein, 1995). The transformative leadership style of DH of MCC Yogyakarta had a significant role to create that supportive environment. In addition, the Department Head consistently instilled the value of local wisdom in MCC Yogyakarta that was "migunani tumraping liyan". This value meant that no matter how small the good we do, it might have a big meaning for others.

This study analyzed the refreezing stage by using the three dimensions of an inclusive climate presented by Nishii \& Rich (2013) which are fair work practices, implementation of integration strategies, and inclusiveness in decision making. The first dimension is fair work practices at MCC Yogyakarta which are demonstrated by inclusive HRM practices. An organization performs fair work practices when equally treat their diverse employees. This is in accordance with the existing work practices at MCC Yogyakarta, namely: the first, the merit-based recruitment system and selection process among non-disabled people and people with disabilities. The second, the policy of extending training time for employees with disabilities according to their disability needs. The third, providing equal job development skills opportunities for employees with disabilities and non-disabled employees. In the second dimension, this study found that the social adaptation process at MCC Yogyakarta has been able to integrate employees with disabilities and non-disabled employees. This finding shows the absence of awkwardness between employees with disabilities and non-disabled employees in socializing in the MCC Yogyakarta office. This condition happened due to the social adaptation strategy implemented at MCC Yogyakarta, namely: the first strategy is implementing an open and intensive bottom-up communication pattern which allows disabled and non-disabled call center agents to convey their opinions, needs, and complaints to higher positions employees such as the team leader or section head. The second strategy is using a lottery system to organize the employees' working cubicles. The third strategy is organizing sports activities together. The fourth strategy is involving disabled employees in the family gathering activities committee. These four integration strategies encourage the social adaptation process of disabled and nondisabled employees very well. 
In addition, this study found that MCC Yogyakarta applying inclusive decision making to determine the work shift division for disabled employees. The decisionmaking process is carried out by gathering input or opinions from all employees then the Department Head of MCC Yogyakarta allows all employees to submit their input in the forum. This method enables employees from all divisions and job positions to express their opinions safely and equally. This method provides various solutions and opportunities for the organization change process. Nevertheless, the Department Head of MCC Yogyakarta only follows up suitable inputs for organization goals.

\section{Conclusion}

This study indicates that The Mandiri Kriya Difabel Program had succeeded in creating an inclusive organizational climate in MCC Yogyakarta. The emergence of this inclusive organizational climate could be weaker or stronger due to the actual organization condition. The DH of MCC Yogyakarta played a significant role in establishing an inclusive climate in MCC Yogyakarta. This condition can negatively impact the organization due to employee rotation schemes. Therefore, there will be a possibility to change back a quasi-stationary equilibrium which possible to discontinue the inclusivity process. Inclusivity studies at the organizational level are still rarely found, especially research that focuses on the process of inclusive organizational change.

Theoretical contribution from this study is providing a new academic reference for researchers and scholars on organizational climate change and human resource management studies, especially about changing organizational climate to be inclusive for people with disabilities by implementing inclusive human resource practices. Meanwhile, the practical contribution from this study is providing an empirical reference for policy makers in making evidence-based policy, and providing a guideline for employers and human resource managers to implement inclusive human resource management practice during employing people with disabilities. The limitation of this research is the simple organizational structure and work units at MCC Yogyakarta cause a simple organizational change process.

\section{Acknowledgement}

This study is part of the author's Master thesis entitled "Mandiri Kriya Difabel: Percikan Semangat dalam Menciptakan Iklim Organisasi Inklusif" and the research was funded by Indonesia Endowment Fund for Education (Lembaga Pengelola Dana Pendidikan/LPDP).

\section{References}

Adami, E. (2009). "We/YouTube": Exploring sign-making in video-interaction. Visual Communication, 8(4), 379-399.

Agbim, K. C. (2013). The impact of organizational structure and leadership styles on innovation. IOSR Journal of Business and Management, 6(6), 56-63. 
Andrews, R., \& Ashworth, R. (2015). Representation and inclusion in public organizations: Evidence from the U.K. civil service. Public Administration Review, 75(2), 279-288.

Barnes, C. (2012). Understanding the social model of disability: Past, present and future. In N. Watson, A. Roulstone, \& C. Thomas (Ed.), Routledge Handbook of Disability Studies (hal. 12-29). New York: Routledge, Taylor and Francis Group.

Belias, D., \& Koustelios, A. (2014). The impact of leadership and change management strategy on organizational culture. European Scientific Journal, 10(7), 451-470.

Berg, B. L., \& Lune, H. (2017). Qualitative research methods for the social sciences. In Pearson Education Limited (9th Editio). Essex: Pearson Education Limited.

Berkowitz, M., \& Johnson, W. G. (1970). Towards an economics of disability: The magnitude and structure of transfer and medical costs. The Journal of Human Resources, 5(3), 271-297.

Brewer, M. B. (1991). The Social Self: On Being the Same and Different at The Same Time. Personality and Social Psychology Bulletin, 17(5), 475-482.

Burnes, B. (2004a). Kurt Lewin and complexity theories: back to the future? Journal of Change Management, 4(4), 309-325.

Burnes, B. (2004b). Kurt Lewin and the planned approach to change: A re-appraisal. Journal of Management Studies, 41(6), 977-1002.

Carrico, A. H. (2014). Discovering diffability: Musical experiences and perspectives of individuals with Williams Syndrome at whispering trails. Florida State University.

Cline, M., Guynes, C. S., \& Nyaboga, A. (2010). The impact of organizational change on information systems security. Journal of Business \& Economics Research (JBER), 8(1), 59-64.

Coghlan, D., \& Rashford, N. S. (2015). Organizational change and strategy: An interlevel dynamics approach. In Organizational Change and Strategy. New York: Routledge, Taylor and Francis Group.

Collins, D. (1998). Organizational change: Sociological perspectives. New York: Routledge, Taylor and Francis Group.

Creswell, J. W. (2007). Qualitative inquiry \& research design: Choosing among five approaches (2nd Editio). California: SAGE Publications, Inc.

de Andrade, P. R. M., Albuquerque, A. B., Teófilo, W. D., \& da Silva, F. A. (2016). Change management: Implementation and benefits of the change control in the information technology environment. International Journal of Advanced Information Technology (IJAIT), 6(1), 23-33.

de Sá, M. A. D., de Melo Oliveira, M. I., Dias, S. M. R. C., \& Barbosa, M. de L. A. (2017). Human resources practices and inclusion of people with disabilities in the hotel industry of Belém, Brazil: a multiple case study. REGE - Revista de Gestão, 24(1), 13-23.

El-Majali, B. A. W. (2016). Organizational culture and its relationship with the organizational climate in the youth higher council from the perspective of council staff. Journal of Education and Practice, 7(8), 39-51. 
Fakih, M. (1999). Akses ruang yang adil: Meletakkan dasar keadilan sosial bagi kaum difabel. Diambil 25 Agustus 2020, dari https://www.suryaden.com/syahadatindonesia/analisis-kritis-diskriminasi-terhadap-kaum-difabel

Ferdman, B. M. (2014). The practice of inclusion in diverse organizations: Toward a systemic and inclusive framework. In B. M. Ferdman \& B. R. Deane (Ed.), Diversity at Work: The Practice of Inclusion (The Profes, hal. 3-54). San Fransisco: John Wiley \& sons, Inc.

Fitzgerald, I., \& Stirling, J. (1999). A slow burning flame? organisational change and industrial relations in the fire service. Industrial Relations Journal, 30(1), 46-60.

Halimatussadiah, A., Nuryakin, C., Muchtar, P. A., Bella, A., \& Rizal, H. (2017). Mapping persons with disabilities (PWDs) in Indonesia labor market. Economics and Finance in Indonesia, 63(2), 126-149.

Hartley, J. (2004). Case study research. In C. Cassell \& G. Symon (Ed.), Essentials Guide to Qualitative Methods in Organizational Research (hal. 323-333). California: SAGE Publications.

Heath, C., Hindmarsh, J. O. N., \& Luff, P. (2010). Video in qualitative research: Analysing social interaction in everyday life. California: SAGE Publications, Inc.

Hehir, T. (2002). Eliminating ableism in education. Harvard Educational Review, 72(1), 132.

Hossan, C. (2015). Applicability of Lewin's change management theory in Australian Local Government. International Journal of Business and Management, 10(6), 5365.

Jansen, W., Otten, S., van der Zee, K., \& Jans, L. (2014). Inclusion: Conceptualization and measurement. European Journal of Social Psychology, 44, 370-385.

Jewitt, C. (2012). An introduction to using video for research (No. 03/12). London.

Kulkarni, M., \& Lengnick-Hall, M. L. (2014). Obstacles to success in the workplace for people with disabilities: A review and research agenda. Human Resource Development Review, 13(2), 158-180.

Latifah, S., \& Himawanto, D. aries. (2017). Aksesibilitas bagi difabel pada bangunan hotel di Kota Surakarta. IJDS: Indonesian Journal of Disability Studies, 4(2), 129-136.

Lewin, K. (1974). Frontiers in group dynamics: Concepts, method and reality in social science, social equilibria and social change. Human Relations, 1(1), 5-41.

Maftuhin, A. (2014). Aksesibilitas ibadah bagi difabel: Studi atas empat masjid di Yogyakarta. INKLUSI: Journal of Disability Studies, 1(2), 249-268.

Maftuhin, A. (2016). Mengikat makna diskriminasi: penyandang cacat, difabel, dan penyandang disabilitas. INKLUSI: Journal of Disability Studies, 3(2), 139-162.

Mcaleese, I., Creed, A., \& Zutshi, A. (2013). A response to critique of the refreeze step in Lewin's model of organizational change from the viewpoint of organizational behavior. International Journal of the Academy of Organizational Behavior Management, January-(4), 104-123.

Miles, M. B., Huberman, A. M., \& Saldana, J. (2014). Qualitative data analysis: a methods sourcebook (3rd Editio). California: SAGE Publications, Inc. 
Miller, F. A., \& Katz, J. H. (2002). Inclusion breakthrough: Unleashing the real power of diversity (1st Editio). Diambil dari https://books.google.de/books?id=4ywy5qxHX10C\&pg=PA41\&hl=de\&source=gbs_ toc_r\&cad $=4 \# v=$ onepage $\& q \& f=f a l s e$

Mills, J. H., Dye, K., \& Mills, A. J. (2008). Understanding organizational change. In Understanding Organizational Change.

Mor Barak, M. E., \& Daya, P. (2014). Fostering inclusion from the inside out to create an inclusive workplace: corporate and organizational efforts in the community and the global society. In B. M. Ferdman \& B. R. Deane (Ed.), Diversity at Work: The Practice of Inclusion (The Profes, hal. 391-412). San Fransisco: John Wiley \& Sons, Inc.

Ndzwayiba, N., \& Ned, L. (2017). The complexity of disability inclusion in the workplace: A South African study. Research in Social Science and Disability, 10, 127-154.

Ningsih, E. R. (2014). Mainstreaming isu disabilitas di masyarakat dalam kegiatan penelitian maupun pengabdian pada masyarakat di STAIN Kudus. Jurnal Penelitian, 8(1), 71-92.

Nishii, L. H. (2013). The benefits of climate for inclusion for gender-diverse groups. Academy of Management Journal, 56(6), 1754-1774.

Nishii, L. H., \& Rich, R. E. (2014). Creating Inclusive Climates in Diverse Organizations. In B. M. Ferdman \& B. R. Deane (Ed.), Diversity at Work: The Practice of Inclusion (The Profes, hal. 330-363). San Fransisco: John Wiley \& sons, Inc.

Oliver, M. (1983). Social work with disabled people (J. Campling, Ed.). Macmillan Education.

Oliver, M. (2019). Understanding Disability: From Theory to Practice. New York: Macmillan Education.

Ostroff, C., Kinicki, A. J., \& Muhammad, R. S. (2013). Organizational culture and climate. In I. B. Weiner (Ed.), Handbook of Psychology (2nd Editio, Vol. 1, hal. 643-676). John Wiley \& sons, Inc.

Otchere-Ankrah, B. (2015). Managing organisational change: The experiencce of driver and vehicle licensing authority (DVLA) of Ghana. International Public Management Review, 16(1), 1-22.

Patterson, A. N. (2018). YouTube generated video clips as qualitative research data: One researcher's reflections on the process. Qualitative Inquiry, 24(10), 759-767.

Purwanta, S. A. (2012). Penyandang disabilitas. In E. Riyadi \& S. Nurhidayat (Ed.), Vulnerable Groups: Kajian dan Mekanisme Perlindungannya (hal. 257-312). Yogyakarta: Pusat Studi Hak Asasi Manusia Universitas Islam Indonesia (PUSHAM UII).

Rahayu, S., Dewi, U., \& Ahdiyana, M. (2013). Pelayanan publik bidang transportasi bagi difabel di Daerah Istimewa Yogyakarta. SOCIA: Jurnal Ilmu-Ilmu Sosial, 10(2), 108119.

Rahmatin, P. N. (2013). Diffability and hope reflected in sean mcnamara's soul surfer movie (2011): an individual psychological approach. Muhammadiyah University of Surakarta. 
Roberson, Q. M. (2006). Disentangling the meanings of diversity and inclusion in organizations. Group and Organization Management, 31(2), 212-236.

Sabharwal, M. (2014). Is diversity management sufficient? Organizational inclusion to further performance. Public Personnel Management, 43(2), 197-217.

Salaman, G., \& Asch, D. (2003). Strategy and capability: Sustaining organizational change. Oxford: Blackwell Publishing Ltd.

Saldana, J. (2011). Fundamentals of qualitative research (Series in; P. Leavy, Ed.). New York: Oxford University Press.

Schein, E. H. (1995). Kurt Lewin's change theory in the field and in the classroom: Notes toward a model of managed learning (No. 3821). Cambridge.

Sellevoll, K. S. (2016). Disability and work barriers to employment. Hendmark University College.

Sen, A. (2000). Development as freedom. New York: Alfred A. Knopf, Inc.

Shier, M., Graham, J. R., \& Jones, M. E. (2009). Barriers to employment as experienced by disabled people: A qualitative analysis in Calgary and Regina, Canada. Disability and Society, 24(1), 63-75.

Shojaei, P., \& Shahabi, H. (2018). Surveying the diffability in Game of Thrones. IJDS:Indonesian Journal of Disability Studies, 5(1), 26-36.

Shore, L. M., Cleveland, J. N., \& Sanchez, D. (2018). Inclusive workplaces: A review and model. Human Resource Management Review, 28(2), 176-189.

Shore, L. M., Randel, A. E., Chung, B. G., Dean, M. A., Ehrhart, K. H., \& Singh, G. (2011). Inclusion and diversity in work groups: $A$ review and model for future research. Journal of Management, 37(4), 1262-1289.

Simons, H. (2014). Case study research: In-depth understanding in context. In P. Leavy (Ed.), The Oxford Handbook of Qualitative Research (hal. 455-470). New York: Oxford University Press.

Sorot Gunung Kidul. (2018). Cerita Nunik, Penyandang Disabilitas yang Kerap Ditolak Perusahaan. Diambil 3 Desember 2020, dari http://gunungkidul.sorot.co/berita94972-siaga-darurat-bencana-sri-sultan-kunjungi-lokasi-banjir.html

Stevens, F. G., Plaut, V. C., \& Sanchez-Burks, J. (2008). Unlocking the Benefits of Diversity: All-Inclusive Multiculturalism and Positive Organizational Change. The Journal of Applied Behavioral Science, 44(1), 116-133. https://doi.org/10.1177/0021886308314460

Suara NTB. (2017). Penyandang Disabilitas Dianaktirikan Perusahaan. Diambil 3 Desember 2020, dari https://www.suarantb.com/penyandang-disabilitas"dianaktirikan"-perusahaan/

Suharto, S., Kuipers, P., \& Dorsett, P. (2016). Disability terminology and the emergence of 'diffability' in Indonesia. Disability and Society, 31(5), 693-712.

Walshe, C., Ewing, G., \& Griffiths, J. (2011). Using observation as a data collection method to help understand patient and professional roles and actions in palliative care settings. Palliative Medicine, 26(8), 1048-1054. 
Wolbring, G. (2008). The Politics of Ableism. Development, 51, 252-258. https://doi.org/10.1057/dev.2008.17

Yeo, R., \& Moore, K. (2003). Including Disabled People in Poverty Reduction Work: "Nothing About Us, without Us." World Development, 31(3), 571-590. https://doi.org/10.1016/S0305-750X(02)00218-8

Yin, R. K. (2003). Case study research: Design and methods. In SAGE Publications, Inc (3rd ed.). California: SAGE Publications, Inc.

Yonnedi, E. (2010). Privatization, organizational change and performance: Evidence from Indonesia. Journal of Organizational Change Management, 23(5), 537-563. 